\title{
Evaluation of the Effect of Seed Treatments, Bactericides, and Cultivars on Bacterial Leaf Spot of Lettuce Caused by Xanthomonas campestris pv. vitians
}

\author{
O. Carisse, A. Ouimet, and V. Toussaint, Horticultural Research and Development Centre, Agriculture and Agri- \\ Food Canada, St-Jean-sur-Richelieu, Quebec J3B 3E6, Canada; and V. Philion, IRDA, St-Hyacinthe, Quebec J2S \\ 7B8, Canada
}

\begin{abstract}
Carisse, O., Ouimet, A., Toussaint, V., and Philion, V. 2000. Evaluation of the effect of seed treatments, bactericides, and cultivars on bacterial leaf spot of lettuce caused by Xanthomonas campestris pv. vitians. Plant Dis. 84:295-299.

As a part of a broader program for management of bacterial leaf spot, the effects of lettuce-seed treatments, greenhouse application of bactericides, and cultivars were evaluated. Seed artificially inoculated with Xanthomonas campestris pv. vitians was treated with bactericides or heat treated and evaluated for the incidence of contaminated seed and seed germination. Seed soaked in $1 \%$ sodium hypochlorite for 5 and $20 \mathrm{~min}$ had an incidence of contaminated seed of less than $10 \%$. Dry-heat $(1 \mathrm{~h})$, hot-water $\left(50^{\circ} \mathrm{C}, 2 \mathrm{~h}\right)$, and organic-acid treatments significantly reduced seed germination. Considering both the effects on incidence of contaminated seed and seed germination, the best treatments were soaking the seeds in $1 \%$ sodium hypochlorite for 5 or 20 min. Copper sulfate, alone or mixed with Zineb or Dithane, failed to control the disease and caused phytotoxicity. All of the other bactericides significantly reduced the severity of bacterial leaf spot. However, the differences among bactericide efficacy were too small to allow comparison between the different forms of copper used, as well as the effect of adding manganese and zinc (Dithane) or zinc alone (Zineb) to the copper product. Nevertheless, copper hydroxide alone, mixed with Zineb or mixed with Dithane, and basic copper sulfate reduced disease severity by $86.89,78.67,80.42$, and $81.82 \%$, respectively, without causing phytotoxicity. For the two years of cultivar evaluation, no significant difference in mean disease severity was observed among the cultivars. Based on disease incidence, the most susceptible cultivar was Bellagreen. Cvs. Ideal cos, Grand Teton, Great Lakes, Paris Island, Ithaca, and Optima showed intermediate susceptibility, and the least-susceptible cultivars were Waldmann's and Grand Rapids, both green-leaf type. There was no significant difference between the three romaine ( $\cos )$ cultivars and between the two crisphead cultivars, but a significant difference was observed between the two butterhead types, Bellagreen and Optima, which had 80.04 and $48.01 \%$, respectively, of their leaves diseased at the time of harvest.
\end{abstract}

Bacterial leaf spot of lettuce, caused by Xanthomonas campestris pv. vitians (Brown) Dye, is a re-emerging disease of lettuce (Lactuca sativa L.) (1,2,12,15, 20,23). Outbreaks were recently reported in California (18), Florida (12), Ohio (13), and Eastern Canada (17). The first symptoms appear at the leaf margin and consist of water-soaked lesions that become necrotic and confluent later in the season. The affected lettuce cannot be sold and is susceptible to other diseases, such as soft rot. By removing the infected leaves at harvest, it is possible to minimize losses due to light and local infections. However, when the disease is severe, management is

Corresponding author: O. Carisse

E-mail: carisseo@em.agr.ca

This research was supported by Agriculture and Agri-Food Canada and the Quebec Vegetable Growers Association.

Accepted for publication 15 November 1999.

Publication no. D-2000-0110-02R

(C) 2000 The American Phytopathological Society difficult or impossible due to lack of pesticides labeled for use in Canada for the control of bacterial leaf spot.

Bacterial leaf spot of lettuce is thought to be seedborne. However, several attempts to re-isolate the bacteria from commercial lots were unsuccessful $(11,18)$. The effect of seed treatment with $0.52 \%$ sodium hypochlorite has been the only seed treatment reported (13) so far, and effect of other treatments, percent active ingredient, and soaking time remain to be established.

In several lettuce-production areas, seeds are planted in plug trays, grown for 28 to 35 days in the greenhouse, and then transplanted into the field. Recently, Wellman-Desbiens (21) showed that X. campestris pv. vitians is disseminated readily from plant to plant with the irrigation water during lettuce transplant production. At the end of the greenhouse-production period evaluated, almost all plants were contaminated with $X$. campestris pv. vitians without showing typical symptoms. This would indicate that $X$. campestris pv. vitians might survive as an epiphyte on lettuce leaves for a long period of time. It is not clear if the absence of symptoms in the greenhouse was due to the low temperature in the greenhouse, to a low population of $X$. campestris pv. vitians, or to other factors which maintained $X$. campestris pv. vitians in an epiphytic rather than in a pathogenic stage. These findings indicate that, if contaminated seeds are used, scouting of lettuce transplants may not allow early detection of the disease before field transplantation. Considering that the population of $X$. campestris $\mathrm{pv}$. vitians starts to build up in the greenhouse and that temperature is unfavorable for disease development, application of bactericides during this period may provide a good means of disease control by maintaining low populations of the pathogenic bacteria.

In 1994 and 1995, in Eastern Canada, symptoms of bacterial leaf spot were observed mainly on cos type (Romaine) lettuce. However, in 1997 and 1998, symptoms were noted on other types of lettuce, including leaf lettuce and crisphead lettuce. Although differences in disease severity have been observed between lettuce types in Florida by Pernezny et al. (12), to our knowledge, there is only one report on cultivar susceptibility (13). More information on individual cultivar resistance is needed, especially on cos-type lettuce, which seems to be the most susceptible to bacterial leaf spot.

The objectives of this study were to evaluate (i) the efficacy of seed treatments in reducing incidence of contaminated seeds, (ii) the efficacy of bactericides applied during greenhouse transplant production, and (iii) variations in susceptibility to $X$. campestris pv. vitians among lettuce cultivars commercially grown in Eastern Canada.

\section{MATERIALS AND METHODS}

Bacterial culture. In all experiments, inoculum was prepared from a liquid culture of $X$. campestris pv. vitians, strain LMG938, grown in nutrient broth (NB, Difco Laboratories, Detroit) for $48 \mathrm{~h}$. The type strain (LMG938) was obtained from Belgium Culture Collection of Microorganisms (BCCM; 19).

Production of $X$. campestris pv. vitians-contaminated seed. Non-coated seed of lettuce (cv. Paris Island) was inoculated following the method described by Salcedo et al. (14). The seed was surface sterilized in sodium hypochlorite $(0.1 \%)$ for $5 \mathrm{~min}$, rinsed three times in 
sterile water, and dried under a laminar flow hood. The treated seed was transferred in a sterile Erlenmeyer flask and a vacuum was applied to the flask for 4 min. The vacuum was removed and $50 \mathrm{ml}$ of bacterial inoculum in NB, adjusted to $10^{8} \mathrm{CFU} / \mathrm{ml}$, was added to the flask and the vacuum was applied again for $4 \mathrm{~min}$. Seed was transferred to a Büchner filter, washed thoroughly with sterile water, placed on a filter paper under a laminar flow hood, and allowed to dry for $4 \mathrm{~h}$. Once dry, the seed was stored at room temperature for a week. Uninfested seed was treated in the same way except that sterile NB was used instead of the bacterial inoculum.

Effect of seed treatments. Chemicals, dry heat, and hot water were evaluated as seed treatments. The following chemical products were tested: $0.1 \%$ and $1 \%$ sodium hypochlorite for 5 and $20 \mathrm{~min}$ (Dutch, Weston, Canada), 7,500 ppm of an organic acid (Lonlife, Jefo Natural Products, SteHyacinthe, Canada) for $20 \mathrm{~min}, 0.25 \%$ cupric acetate for $20 \mathrm{~min}, 0.2 \%$ manganese ethylenebisdithiocarbamate (EBDC) (Maneb, Elf Atochem North America Inc., Philadelphia) for $20 \mathrm{~min}, 550 \mathrm{ppm}$ of streptomycin sulfate (Agristrep, Source Thechnology, Biologicals Inc, NY) for 20 min, and $1 \%$ triple potassium salt (Virkon, Antec International, Sudbury, UK) for $20 \mathrm{~min}$. Seed treated in water served as a control. The efficacy of hotwater treatment was determined by soaking seeds in water maintained at $50^{\circ} \mathrm{C}$ for $20 \mathrm{~min}, 1 \mathrm{~h}$, and $2 \mathrm{~h}$. For the dry-heat treatments, seed was placed in an isotemp incubator (model 338F, Fisher Scientific Co., Pittsburgh) maintained at $50^{\circ} \mathrm{C}$ during $20 \mathrm{~min}$ and $1 \mathrm{~h}$.

For each treatment (total of 16 treatments), $1 \mathrm{~g}$ of infested seed was put in cheesecloth and soaked in the chemical products or hot water for a given period of time. For the dry-heat treatment, seed was placed in glass petri dishes. To evaluate the effect of the seed treatments on incidence of contaminated seed, 100 treated seeds were dried under a laminar flow hood, covered with a filter paper, and squashed with a pestle. The seeds were then trans-

Table 1. Description of pesticides evaluated for the control of bacterial leaf spot of lettuce during transplant production ${ }^{\mathrm{z}}$

\begin{tabular}{llcc}
\hline Active ingredient & \multicolumn{1}{c}{$\begin{array}{c}\text { Commercial } \\
\text { name }\end{array}$} & $\begin{array}{c}\text { Concentration } \\
\text { (g/liter) }\end{array}$ & $\begin{array}{c}\text { Metallic } \\
\text { copper }(\%)\end{array}$ \\
\hline Copper hydroxide $77 \%\left(\mathrm{Cu}(\mathrm{OH})_{2}\right)$ & Kocide 101 & 4.5 & 0.23 \\
Zinc ethylene bis (dithiocarbamate) (Zineb) & Zineb & 4.8 & $\ldots$ \\
Manganese ethylene bis(dithiocarbamate) $(\mathrm{Maneb})$ & Dithane $\mathrm{M}-22$ & 5.5 & $\ldots$ \\
Cupric sulfate pentahydrate, $\mathrm{CuSO}_{4}\left(\mathrm{H}_{2} \mathrm{O}\right)_{5}$ & Phyton 27 & 5.5 & 0.03 \\
Basic cupric chloride, $3 \mathrm{Cu}(\mathrm{OH})_{2} \mathrm{CuCl}_{2}$ & Fixed copper (FC) & 9.0 & 0.45 \\
Basic copper sulfate & Basic copper 53 & 5.8 & 0.31 \\
Unknown organic acid extract from citrus seed & Lonlife & $\ldots$ & $\ldots$ \\
\hline
\end{tabular}

${ }^{\mathrm{z}}$ Sources of products: Kocide 101, Griffi Corporation, GA; Zineb, United Agri-Products, Ontario, Canada; DithaneM-22, Rohm and Hass, Ontario, Canada; Phyton 27, Source Technology, Biologicals Inc., NY; Fixed copper, United Agri-Products, Ontario, Canada; Basic copper 53, United AgriProducts, Ontario, Canada; and Lonlife, Jefo Natural Products, Ste-Hyacinthe, Canada. tray, selected arbitrarily, were evaluated for disease symptoms. Severity was rated on a scale of 0 to 5 , where $0=$ no symptoms, $1=1$ to 5 distinct spots at the leaf margin, 2 = several spots with coalescence, 3 = lesions dispersed on the entire surface of the leaf, $4=$ yellowing and slight wilting, and $5=$ dead leaf. Disease severity was expressed as the total amount of disease per plant (summation of all scores). The experiment was conducted as a completely randomized block design with 16 treatments (15 pesticides and water) and four blocks. The experiment was conducted twice.

Evaluation of lettuce cultivars for susceptibility to bacterial leaf spot. Cultivar susceptibility was evaluated under field conditions at the experimental farm of Agriculture and Agri-Food Canada, in SteClotilde, Quebec, Canada. On 23 July 1997 and 24 July 1998, greenhouse-grown lettuce seedlings were planted in the field. Nine lettuce cultivars were evaluated for bacterial leaf spot susceptibility: cos type (cvs. Paris Island, Ideal cos, and Grand Teton); green-leaf type (cvs. Waldmann's and Grand Rapids); crisphead type (cvs. Ithaca and Great Lakes); and butterhead type (cvs. Optima and Bellagreen). Lettuce seedlings were planted $0.30 \mathrm{~m}$ apart in rows with $0.40 \mathrm{~m}$ between rows, with seven plants per row and three rows per cultivar per block. Lettuce was grown according to the Quebec guide for vegetable production (3). The lettuce plants were inoculated on the day following transplantation and 1 day before transplantation in 1997 and 1998, respectively; in both years, inoculation occurred on a cloudy day. The bacterial suspension was optically adjusted at a concentration corresponding to about $10^{4} \mathrm{CFU} / \mathrm{ml}$. Plants were sprayed in the morning with the bacterial suspension using a hand sprayer at a rate of approximately $1 \mathrm{ml} /$ plant. Immediately after inoculation, plants were enclosed in plastic bags for at least $24 \mathrm{~h}$. Every week, disease severity and incidence were evaluated on three plants located in the middle row for a total of nine plants per cultivar and rated based on the scale previously described. The experiment was conducted twice as a completely randomized block design with nine cultivars and three blocks.

Statistical analysis. Tests of homogeneity of variances ( $F$ test) were conducted to determine if data from the two experimental runs could be pooled and to ensure that the underlying assumptions of the statistical models were respected. Analysis of variance was used to test the effect of seed treatments on incidence of contaminated seed and of the effect of pesticides on disease severity. Multiple comparison tests (least significant difference; LSD) were used to compare means. Linear contrasts were used to compare different levels of treatments, with the control at the 0.05 confidence level. 


\section{RESULTS}

Effect of seed treatments. Results of the two experimental runs were similar and variances were homogenous; therefore, analysis of variance was conducted on pooled data. All treatments, except Maneb, dry heat for $20 \mathrm{~min}$ and $1 \mathrm{~h}$, and hot water for $20 \mathrm{~min}$ and $1 \mathrm{~h}$, significantly reduced incidence of contaminated seed (Fig. 1). However, only the treatments with $1 \%$ sodium hypochlorite for 5 and $20 \mathrm{~min}$ resulted in incidence of contaminated seed of less than $10 \%$. Overall, seed germination was low, with a maximum of $54.3 \%$ observed for the seed treated with $0.1 \%$ sodium hypochlorite for $5 \mathrm{~min}$. The germination potential of the seed lot was about 50 to $55 \%$ with non-treated seeds. Most treatments did not significantly reduce seed germination, except for dry heat for $1 \mathrm{~h}$, hot water for 1 and $2 \mathrm{~h}$, and the organic acid, which reduced seed germination by $91.7,68.0,92.9$, and $56.9 \%$, respectively (Fig. 1). Considering both the effects on incidence of contaminated seed and seed germination, the best treatments were $1 \%$ sodium hypochlorite for soaking times of 5 and $20 \mathrm{~min}$.

Effect of bactericides on disease severity during transplant production. In general, disease severity was lower in the second trial than in the first trial, with mean disease severity of 2.7 and 8.7 , respectively. Treatments with Phyton alone or Phyton mixed with Zineb or Dithane failed to control the disease (Fig. 2), and disease severity was significantly higher than on the control treated with water. In addition, lettuce leaves treated with Phyton showed severe symptoms of phytotoxicity and older leaves dropped prematurely. All other treatments significantly reduced the severity of bacterial leaf spot (Fig. 2). However, the differences in disease severity among the treatments were too small to allow comparison among the different forms of copper used as well as the effect of adding EBDC-coordinated metallic ions of manganese and zinc (Dithane) or zinc alone (Zineb) to the copper products. Nevertheless, treatments with Kocide alone, Kocide mixed with Zineb, Kocide mixed with Dithane, and the treatment using Basic copper 53 reduced disease severity by $78.67,80.42,81.82$, and $86.89 \%$, respectively, without causing phytotoxicity.

Evaluation of lettuce cultivar for susceptibility to bacterial leaf spot. Mean disease severity per leaf varied from 2.22 on cv. Great Lakes to 1.72 on cv. Grand Rapids. However, for the two years of the experiment, no significant difference was observed in disease severity among the cultivars. Significant differences were observed for disease incidence. Based on disease incidence, $\mathrm{cv}$. Bellagreen was the most susceptible, with $80.04 \%$ of diseased leaves at the end of the growing season. Cvs. Ideal cos, Grand Teton, Great Lakes, Paris Island, Ithaca, and Optima showed intermediate susceptibility, with disease incidence that varied from 67.72 to 48.01
(Table 2). The least susceptible cultivars were Waldmann's and Grand Rapids, both green-leaf types, with disease incidence of 42.88 and 42.07, respectively. Based on disease incidence, there was no significant difference among the three romaine (cos) cultivars and among the two crisphead cultivars. This was not the case for the two butterhead cultivars, Bellagreen and Optima, which had 80.04 and $48.01 \%$, respectively, of their leaves diseased at the time of harvest (Table 2).

\section{DISCUSSION}

$X$. campestris pv. vitians is most probably seedborne $(11,13,18)$. Consequently, seed treatment may offer a practical means of disease control. There is only one report of seed treatment, by Sahin and Miller (13), who tested the effect of $0.52 \%$ sodium hypochlorite for a 5-min soaking time. They recovered $X$. campestris pv. vitians from only 1 out of 3,000 seeds treated, as compared to $10.5 \%$ for the untreated seed. In their study, Sahin and Miller (13) tested only hypochlorite at $0.52 \%$ and it was not possible to conclude the best concentration and soaking time from their study. In the present study, 16 seed treatments were evaluated and it was concluded that 5 and 20 min of soaking in $1 \%$ sodium hypochlorite were the most efficient treatments in reducing incidence of infested seed without affecting seed germination. Chemical seed treatments for the control of seedborne pathogens have

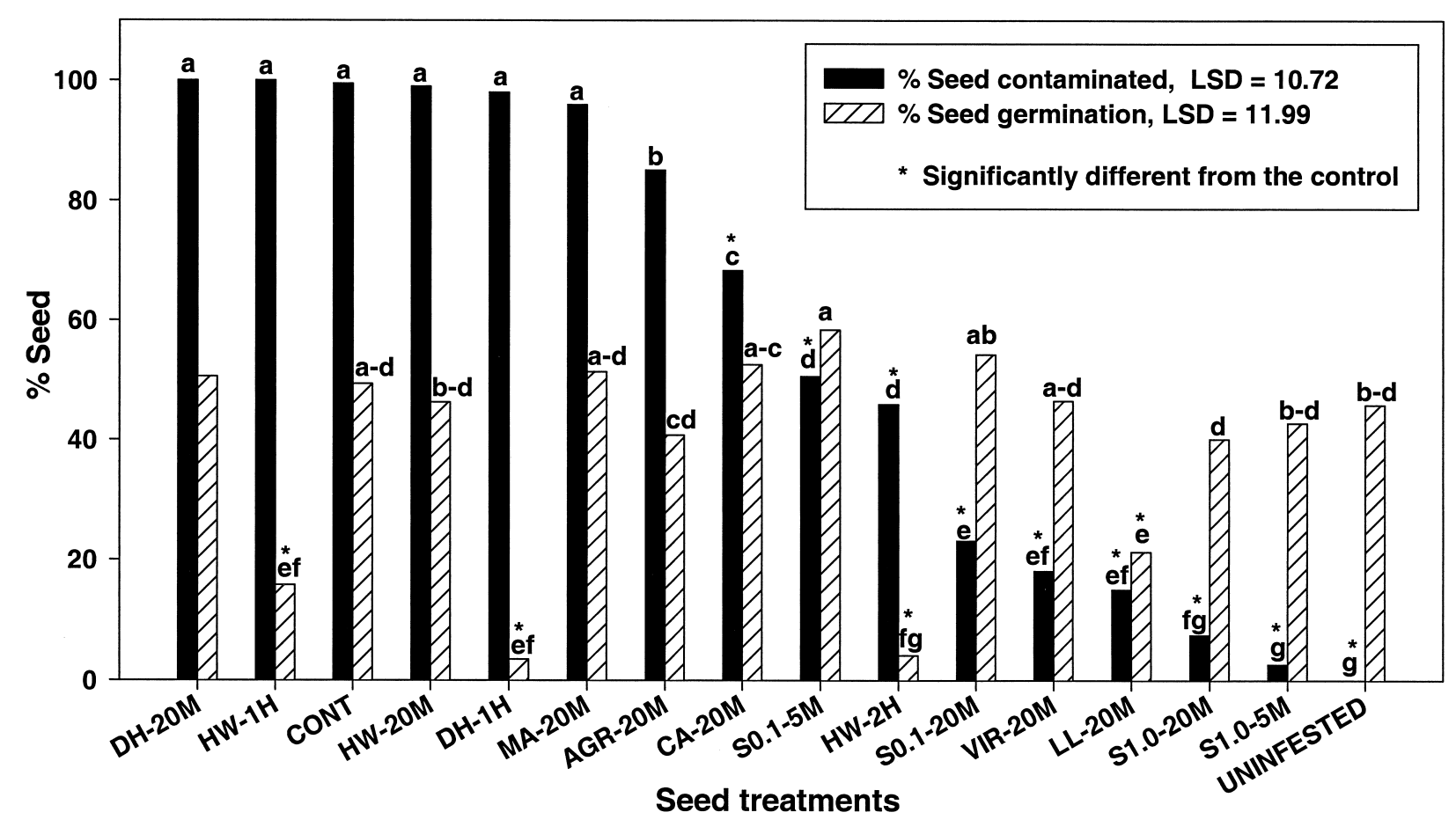

Fig. 1. Effect of seed treatment on lettuce seed contamination by Xanthomonas campestris pv. vitians and seed germination. Treatments: DH-20M (dry heat, $20 \mathrm{~min}$ ); HW-1H (hot water $1 \mathrm{~h}$ ); CONT (contaminated seed); HW-20M (hot water, $20 \mathrm{~min}$ ); DH-1H (dry heat, $1 \mathrm{~h}$ ); MA-20M (Maneb, 20 min); AGR-20M (Agristrep, $20 \mathrm{~min}$ ); CA-20M (cupric acetate); S0.1-5M (sodium hypochlorite $0.1 \%, 5$ min); HW-2H (hot water, $2 \mathrm{~h}$ ); S0.1-20M (sodium hypochlorite 0.1\%, $20 \mathrm{~min}$ ); VIR-20M (Virkon, $20 \mathrm{~min}$ ); LL-20M (Lonlife, $20 \mathrm{~min}$ ) S1-20M (sodium hypochlorite 1\%, 20 min); S1-5M (sodium hypochlorite $1 \% 5 \mathrm{~min}$ ); UNINFESTED (uncontaminated seed). 
been highly successful $(4,6,7)$. Furthermore, seed treatment requires small amounts of pesticides and, consequently, their environmental impacts are quite low (8). Common seed treatments, such as chlorine salts, antibiotics, or hot water, are efficient for several bacterial diseases (9). For instance, McIntyre et al. (10) reported the control of Erwinia carotovora pv. carotovora by soaking the seeds in hot water $\left(50^{\circ} \mathrm{C}\right)$ for $12 \mathrm{~min}$. Pseudomonas glumae can be eradicated from rice seeds by dry-heat treatment ( 2 days at $\left.65^{\circ} \mathrm{C}\right)$ without affecting seed germination (22). In our experiment, however, dry heat for 20 min or $1 \mathrm{~h}$ and a hot-water treatment for 1 $\mathrm{h}$ did not significantly reduce incidence of contaminated seed. Hot-water treatment for $2 \mathrm{~h}$ was somewhat efficient in reducing seed contamination but greatly affected seed germination.

There are only a few reports of chemical control of this disease. In 1964, Schroth et al. (15) tested the efficiency of fixed-copper sprays in greenhouse trials and reported that concentrations of fixed copper below

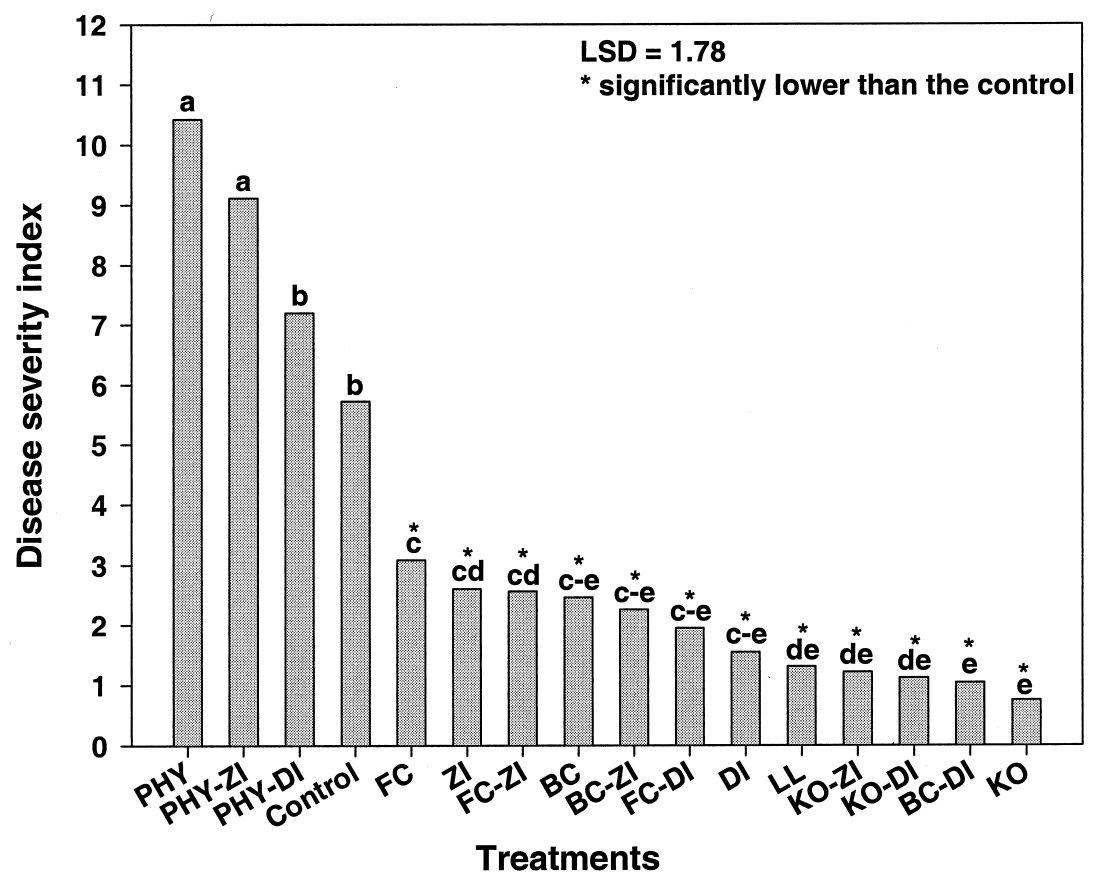

Fig. 2. Effect of pesticides on development of bacterial leaf spot during lettuce-transplant production in the greenhouse. $\mathrm{PHY}=$ cupric sulfate pentahydrate (Phyton 27); FC = basic cupric chloride (fixed copper); $\mathrm{BC}=$ basic copper sulfate (basic copper 53 ); $\mathrm{KO}=$ copper hydroxide (Kocide); $\mathrm{ZI}=$ zinc ethylene bis(dithiocarbamate) (Zineb); DI = manganese ethylene bis(dithiocarbamate) (Dithane); LL $=$ organic acid $($ Lonlife); control $=$ water.

Table 2. Bacterial leaf spot disease severity and disease incidence for lettuce cultivars inoculated with Xanthomonas campestris pv. vitians ${ }^{\mathrm{w}}$

\begin{tabular}{llccc}
\hline Cultivar & Lettuce type & Disease severity $^{\mathbf{x}}$ & Disease incidence $^{\mathbf{y}}$ & AUDPC $^{\mathbf{z}}$ \\
\hline Bella Green & Butterhead & $2.18 \mathrm{a}$ & $80.04 \mathrm{a}$ & $3.42 \mathrm{a}$ \\
Ideal cos & Romaine $(\cos )$ & $1.94 \mathrm{a}$ & $67.72 \mathrm{~b}$ & $-0.04 \mathrm{~b}$ \\
Grand Teton & Romaine $(\cos )$ & $2.06 \mathrm{a}$ & $67.51 \mathrm{~b}$ & $-2.77 \mathrm{bcd}$ \\
Great Lakes & Crisphead & $2.22 \mathrm{a}$ & $60.14 \mathrm{bc}$ & $-1.91 \mathrm{bc}$ \\
Paris Island & Romaine $(\cos )$ & $1.79 \mathrm{a}$ & $59.81 \mathrm{bc}$ & $-4.12 \mathrm{~cd}$ \\
Ithaca & Crisphead & $1.95 \mathrm{a}$ & $50.07 \mathrm{~cd}$ & $-2.28 \mathrm{bcd}$ \\
Optima & Butterhead & $1.77 \mathrm{a}$ & $48.01 \mathrm{~cd}$ & $-3.47 \mathrm{~cd}$ \\
Waldmann's & Green leaf & $1.83 \mathrm{a}$ & $42.88 \mathrm{~d}$ & $-4.98 \mathrm{~d}$ \\
Grand Rapids & Green leaf & $1.72 \mathrm{a}$ & $42.07 \mathrm{~d}$ & $-4.07 \mathrm{~cd}$ \\
LSD & $\ldots$ & 0.66 & 12.14 & 3.00 \\
\hline
\end{tabular}

${ }^{\text {w}}$ Values in the same column with the same letter are not significantly different according to the least significant difference (LSD) test $(P=0.05)$

${ }^{x}$ Average disease severity index for the two experiments carried out in 1997 and 1998, each with nine replications. Severity was rated at harvest when plants were 50 days old, on a scale of 0 to 5 , where $0=$ no symptoms, $1=1$ to 5 distinct spots at the leaf margin, $2=$ several spots with coalescence, 3 = lesions dispersed on the entire surface of the leaf; $4=$ yellowing and slight wilting, and 5 $=$ dead leaf. Disease severity was expressed as the total amount of disease per plant (summation of all scores).

${ }^{y}$ Average diseased incidence at harvest for the two experiments, each with nine replications.

${ }^{\mathrm{z}}$ Area under the disease progress curve (AUDPC) was computed using the trapezoidal integration of disease incidence over time using the formula proposed by Shaner and Finney (16). phytotoxicity levels (less than $0.1 \%$ metallic copper) were not effective in controlling bacterial leaf spot of lettuce. In the present study, solutions of fixed copper containing $0.45 \%$ metallic ions did not cause the phytotoxicity which was observed on plants treated with copper-sulfate solution containing $0.03 \%$ metallic ions. The concentration of metallic copper tested varied from 0.03 to 0.45 ; however, no correlation between percent metallic copper and efficacy was observed. In general, the addition of Dithane, which contains both zinc and manganese, increased the efficiency of the copper-based products tested, except for Phyton 27. The best disease control was obtained with Basic copper 53 and Kocide mixed with Dithane, although there were no significant differences in disease control among products and mixtures of products tested. Our results are similar to those reported for other bacterial diseases, including $X$. campestris pv. vesicatoria (5). These authors reported that the best control was obtained with copper hydroxides mixed with mancozeb, even though no significant differences between the two treatments could be detected.

Pernezny et al. (12) reported that romaine $(\cos )$ and butterhead types were more susceptible to several strains of $X$. campestris pv. vitians than crisphead lettuce. Sahin and Miller (13) evaluated nine commercial cultivars grown in Ohio and reported that only the red leaf cv. Redline was resistant to the disease. Our results are in accordance with those reported in these studies because we observed that the most susceptible cultivars are butterhead (Bellagreen) and romaine type (Grand Teton and Ideal cos) and the two least-susceptible cultivars were green-leaf types. In both Sahin and Miller (13) and Pernezny et al. (12), disease rating was done on a per-plant basis. In our evaluation, we looked at each individual leaf and noted that there was no significant difference in disease severity on diseased leaves among the cultivars tested, but significant differences were observed for disease incidence (proportion of diseased leaves per plant). This can be explained, in part, by the difference in the number of leaves per cultivar. In other words, once a leaf is infected, disease severity remains the same regardless of the cultivar. When evaluating different lettuce types, a per-plant evaluation may be biased because the different types produce a number of leaves than can vary from 15 to 30 at harvest time.

Management of bacterial leaf spot based on a single control measure is probably insufficient to achieve commercially acceptable control. Integrated management could include disease-tolerant cultivars, seed treatments, and seedling-treatment (during transplant production) sprays with either Basic copper 53 or Kocide combined with Dithane, depending on local practices and regulations. 
LITERATURE CITED

1. Boesewinkel, H. J. 1977. A new disease of lettuce. N. Z. J. Agric. 134:54.

2. Burkholder, W. H. 1954. Three bacteria pathogenic on head lettuce in New York state. Phytopathology 44:592-596.

3. C.P.V.Q. 1987. Légumes: protection. Ministère de l'Agriculture, des Pêcheries et de l'Alimentation du Québec. Agdex 250-605.

4. Humaydan, H. S., Harman, G. E., Nedrow, B. L., and DiNitto, L. V. 1980. Eradication of Xanthomonas campestris, the causal agent of black rot from Brassica seeds with antibiotics and sodium hypochlorite. Phytopathology 70:127-131.

5. Jones, J. B., Jones, J. P., and Woltz, S. S. 1993. The effect of selected bactericides on population dynamics of Xanthomonas campestris pv. vesicatoria on tomato leaflets. Proc. Fla. State Hortic. Soc. 106:160-163

6. Leben, C. 1983. Chemicals plus heat as a seed treatment for the control of angular leaf spot of cucumber seedlings. Plant Dis. 67:991-993.

7. Lockhart, C. L., Gourley, C. O., and Chipman, E. W. 1976. Control of Xanthomonas campestris in Brussels sprouts with hot water and aureomycin seed treatment. Can. Plant Dis. Surv. 56:63-66.

8. Mathre, D. E., Johnston, R. H., Callan, N. W., Mohan, S. K., Martin, J. M., and Miller, J. B. 1995. Combined biological and chemical seed treatments for the control of two seedling diseases of Sh2 sweet corn. Plant Dis. 79:1145-
1148.

9. Maude, R. B. 1996. Seedborne Diseases and Their Control: Principles and Practice. CAB International, Oxon, UK.

10. McIntyre, J. L., Sands, D. C., and Taylor, G. S. 1978. Overwintering, seed disinfestation and pathogenicity studies of the tobacco hollow stalk pathogen, Erwinia caratovora var. caratovora. Phytopathology 68:435-440.

11. Ohata, K., Serizana, S., Azegami, K., and Shirata, A. 1982. Possibility of seed transmission of Xanthomonas campestris pv. vitians, the pathogen of bacterial spot of lettuce. Bull. Natl. Inst. Agric. Sci. (Japan) 36:81-88.

12. Pernezny, K., Raid, R. E., Stall, R. N., Hodge, N. C., and Collins, J. 1995. An outbreak of bacterial leaf spot of lettuce in Florida caused by Xanthomonas campestris pv. vitians. Plant Dis. 79:359-360.

13. Sahin, F., and Miller, S. A. 1997. Identification of the bacterial leaf spot pathogen of lettuce, Xanthomonas campestris pv. vitians, in Ohio, and assessment of cultivar resistance and seed treatment. Plant Dis. 81:1443-1446.

14. Salcedo, G., Ramirez, M. E., Flores, C., and Galindo, E. 1992. Preservation of Xanthomonas campestris in Brassica oleracea seeds. Appl. Microbiol. Biotechnol. 37:723-727.

15. Schroth, M. N., Thompson, J. P., Bardin, R., and Greathead, A. 1964. A new disease in California... Bacterial spot of lettuce. Calif. Agric. Nov:2-3.

16. Shaner, G., and Finney, R. E. 1977. The effect of nitrogen fertilization on the expression of slow-mildewing resistance in knox wheat. Phytopathology 67:1051-1056.

17. Toussaint, V., Morris, C. E., and Carisse, O 1998. Identification, resistance to antibiotics and utilization of carbon sources by Xanthomonas campestris pv. vitians strains isolated from different lettuce growing areas. Seventh Int. Congr. Plant Pathol. August 1998. Edinburgh, Scotland.

18. Umesh, K. C., Koike, S. T., and Gilbertson, R. L. 1996. Association of Xanthomonas cam pestris pv. vitians with lettuce seed. (Abstr.) Phytopathology 86:S3.

19. Vauterin, L., Hoste, B., Kersters, K., and Swings, J. 1995. Reclassification of Xanthomonas. Int. J. Syst. Bacteriol. 45:472-489.

20. Wallis, F. M., and Joubert, J. J. 1972. Bacterial leafspot of lettuce in Natal. Phytophylatica 4:137-138.

21. Wellman-Desbiens, W. 1999. Études sur les sources de contamination par les bactéries responsables de la nervation noire du chou et de la nécrose marginale de la laitue. M.Sc. Thesis, Sherbrooke University.

22. Zeigler, R. S., and Alvarez, E. 1989. Grain discoloration of rice caused by Pseudomonas glumae in Latin America. Plant Dis. 73:368.

23. Zoina, A., and Volpe, E. 1992. Epidemiological aspects of lettuce bacterial spot induced by Xanthomonas campestris pv. vitians. Plant Pathogenic Bacteria, Versailles (France). Ed INRA, Paris, 1994. Les Colloques 66:797-802. 